\title{
Non-Specific Immune Response of Vanname Shrimp \\ (Litopeaneus vanname) Induced by Chitosan as an Immunomodulator against IMNV (Infectious Myonecrosis Virus) Exposure
}

\author{
Daruti Dinda Nindarwi \\ Magister Degree, Faculty of Fisheries and Marine Science Brawijaya University
}

\section{Uun Yanuhar}

Faculty of Fisheries and Marine Science Brawijaya University (Promotor), Indonesia

Sukoso

Faculty of Fisheries and Marine Science Brawijaya University (Promotor), Indonesia

Received: June 10, 2013 Accepted: June 25, 2013

doi:10.5296/jbls.v4i2.4086 URL: http://dx.doi.org/10.5296/jbls.v4i2.4086

\begin{abstract}
Chitosan is one of polysaccharide derivatives commonly known as poly D-glucosamin-2 amino-2 dexoy-D-glucose, and glucosamine has a nearly similar chemical structure with $\beta$-glucan. It is capable of activating Prophenoloxidase (ProPO) to enhance immune system of shrimp. Chitosan is added to the food with treatment dose of $3 \mathrm{ml}, 6 \mathrm{ml}, 9 \mathrm{ml}$, and $12 \mathrm{ml}$. Then one negative control (not infected with IMNV) and one positive control (infected with IMNV). Shrimps are infected with IMNV through injection and THC, DHC, phagocytosis activity, super anionoxide and phenoloxidase (PO) are carefully observed. The most optimum result was obtained in the treatment of $3 \mathrm{ml}$ Chitosan/ $\mathrm{kg}$ food and the lowest result was found in the positive control.
\end{abstract}

Keywords: Chitosan, Immune system of shrimp, Immunostimulant, Phenoloxidase. 


\section{Introduction}

Disease is considered as the most common factor to cause failure in the culture of vanname shrimp (Litopeaneus vanname) in Indonesia. One of the causing diseases known is a disease caused by IMNV (Infectious Myonecrosis Virus). Development of IMNV is a very rapid process in the cultural pond and it is potential to cause up to $80 \%$ of mortality. Various efforts were performed to overcome IMNV infection, and the most effective method is currently believed to enhance immune system through immunostimulant administration.

Chitosan is a polysaccharide produced through chitin deacetylation. Based on the opinion of Bashir et al. (2001), chitosan is one of polysaccharide derivatives and it mainly consists of glucosamine, 2 amino-2dexoy- $\beta$-D-glucose or more commonly known as Poly D-glucosamine $(\beta(1,4)$ 2-amino-2 deoxy-D-glucose). Presscot et al., (1996) stated that glucosamine is a polymer derivative of microorganism's cellular membrane which is nearly similar with lipopolysaccharide, one type of $\beta$-glucan. Therefore, in this case, it is expected that plasma in hemolim can recognize glucosamine and further increase number of hemocytes and activate PPA (Active Serine Protease) to stimulate production of phenoloxidase enzyme. This study is aiming to observe non-specific immune response of vanname shrimp (L. vanname) induced with chitosan added into food against IMNV (Infectious Myonecrosis Virus) infection through the measurement of THC, DHC, phagocytosis activity, value of super anionoxide and phenoloxidase (PO).

\section{Materials and Methods}

\subsection{Materials and Tools}

Vanname shrimps used in this study were of F1 quality, and SPF (Specific Pathogen Free) certified, obtained from PT Suma Benur Situbondo-Jawa Timur, sized 4 grams. Chitosan is a commercial liquid chitosan with composition of 1 gram chitosan dissolved in $100 \mathrm{ml}$ acetic acid $2 \%$ in the ratio of 1:100 (b/v), commercial food from PT Centra Proteina Prima of Irawan brand. Materials used in the hemolim test are: gymsa, anticoagulant KC-199, L cystein and glutaraldehyde, buffer CAC, L-Dopa and trypsine and tyrosine.

Equipments used: tarpaulin tub $1 \times 1 \times 1 \mathrm{~m}$, aeration equipment, digital scale, syringe $0.1 \mathrm{ml} 27.5$ G, PCR tool, light microscope, hand tally counter, digital camera, microtube, pastel pellets, centrifuge, vortex, haemocytometer, object glass, cover glass, freezer with temperature $-80^{\circ} \mathrm{C}$ and micro filter $0.45 \mu \mathrm{L}$.

\subsection{Methods}

Vanname shrimp (L. vanname) of \pm 4 grams weight acclimatized in the tarpaulin tub, each tub filled with 50 shrimps. Liquid chitosan was added into food with 6 different treatments A: $3 \mathrm{ml}$; B: $6 \mathrm{ml}$; C: $9 \mathrm{ml}$; D: $12 \mathrm{ml} / \mathrm{kg}$ food, E: as a negative control (without IMNV infection) and F: as positive control (infected with IMNV). Chitosan was given for 3 weeks (21 days). Food administration was done 4 times in a day. IMNV challenge test was given through injection and data before and after challenge test were observed. 


\section{Result and Discussion}

Results were obtained after IMNV challenge. The levels of immune response were measured through recording THC (Total Hemocyte Count), DHC (Differential Hemocyte Count), phagocytosis activity, and absorbance value of anion superoxide and phenoloxidase (PO).

\subsection{Total Haemocyte Count (THC)}

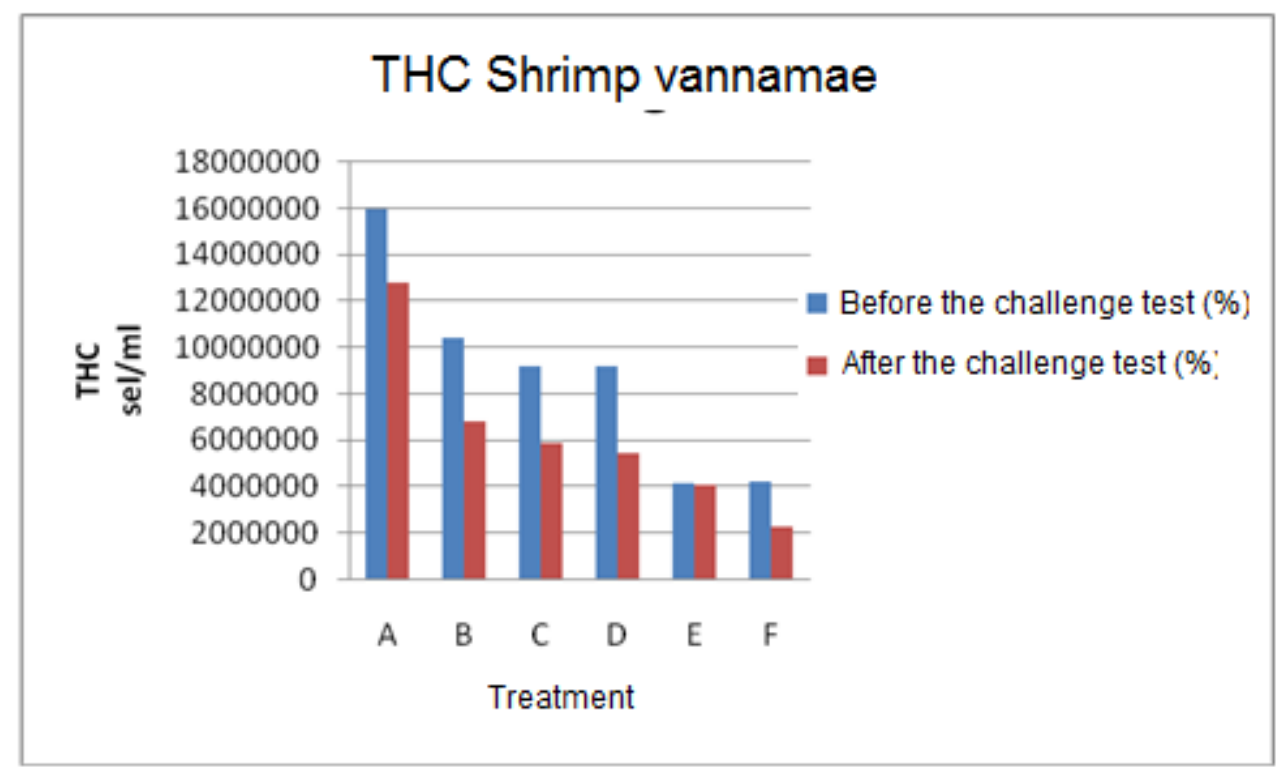

Figure 1. Graphic number of THC of vanname shrimp before and after IMNV challenge test. Treatment A (3 ml); B (6 ml); C (9 ml); D (12 ml); E (0 ml/negative control); F (0 ml/positive control) per $\mathrm{kg}$ food.

Figure 1 explained that the highest number of THC before challenge test is found in treatment A $3 \mathrm{ml} / \mathrm{kg}$ food and the lowest THC number is in control treatment (without chitosan). The high number of THC in shrimp in the treatments showed that chitosan is capable of enhancing immune response, this is in line with the opinion of Van de Braak (2000), Felix et al., (2004), Wang and Cheng (2004) and Yin et al., (2006) stating that the increasing number of THC indicated an increase of both cellular and humoral immune response.

The total number of hemocytes before IMNV challenge test was higher than control. Hemocytes in shrimp hemolim increased due to the existence of lectin molecules functioning in the recognition of foreign material entering body (Rodriguez and Le Moullac, 2000). Chitosan is a polysaccharide derivative consisting of glucosamine, and lectin molecules recognize it. Lectin will react with glucosamine which then produce hemocytes and increase pro phenoloxidase system.

Total number of hemocytes after challenge test is decreasing, it indicates pathogenic infection caused by IMNV infecting hemocytes. It leads to the loss of hemocytes in hemolim. Van de Braak (2002) stated that a decrease of hemocytes is caused by pathogenic infection, this is because hemocytes are target for pathogens. 


\section{Macrothink}

\subsection{Differential Hemocyte Count (DHC)}

Observation on DHC aimed at identifying pattern of change of hyalin cells, semi-granular cells and granular cells percentage in hemolim before and after IMNV challenge test
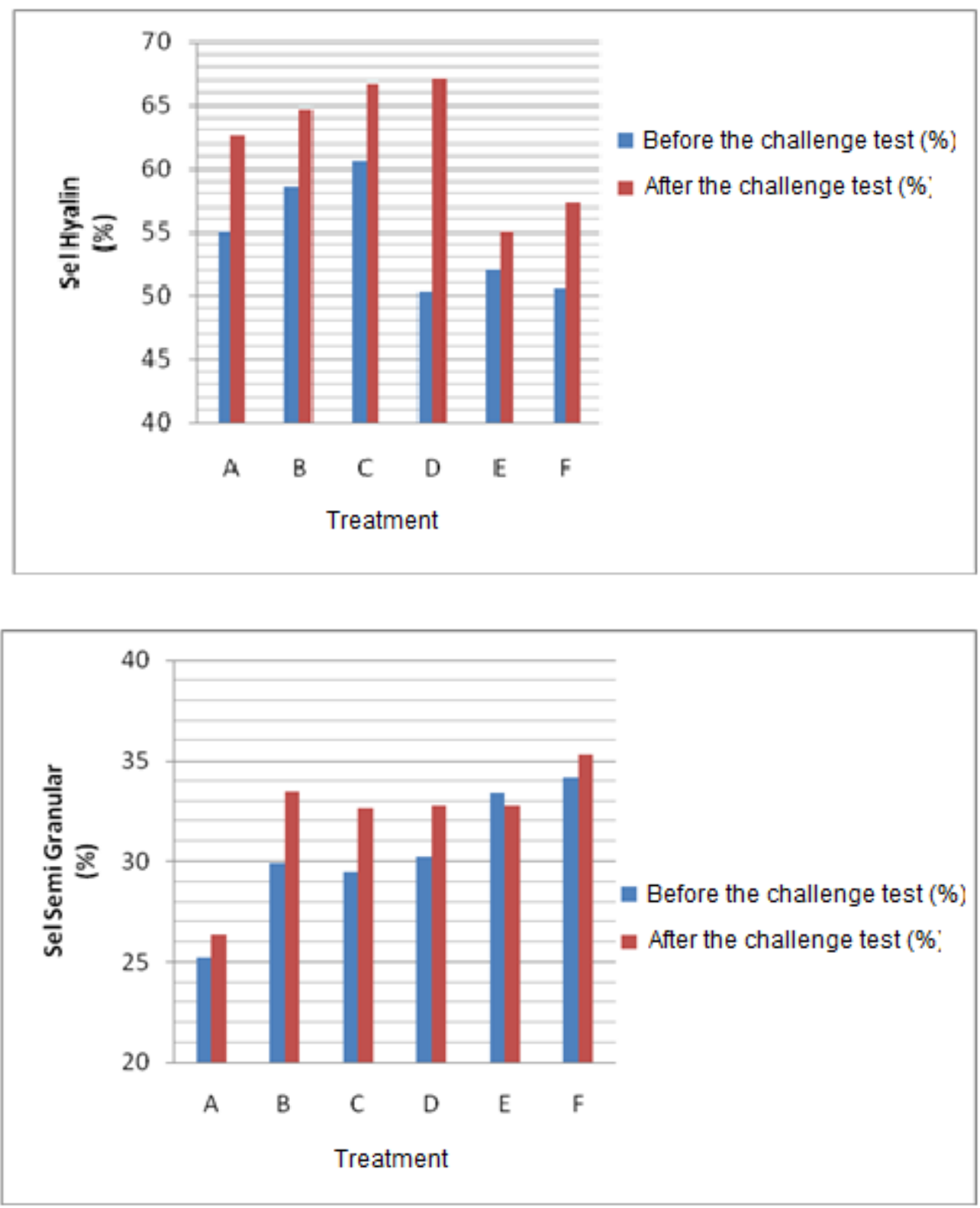


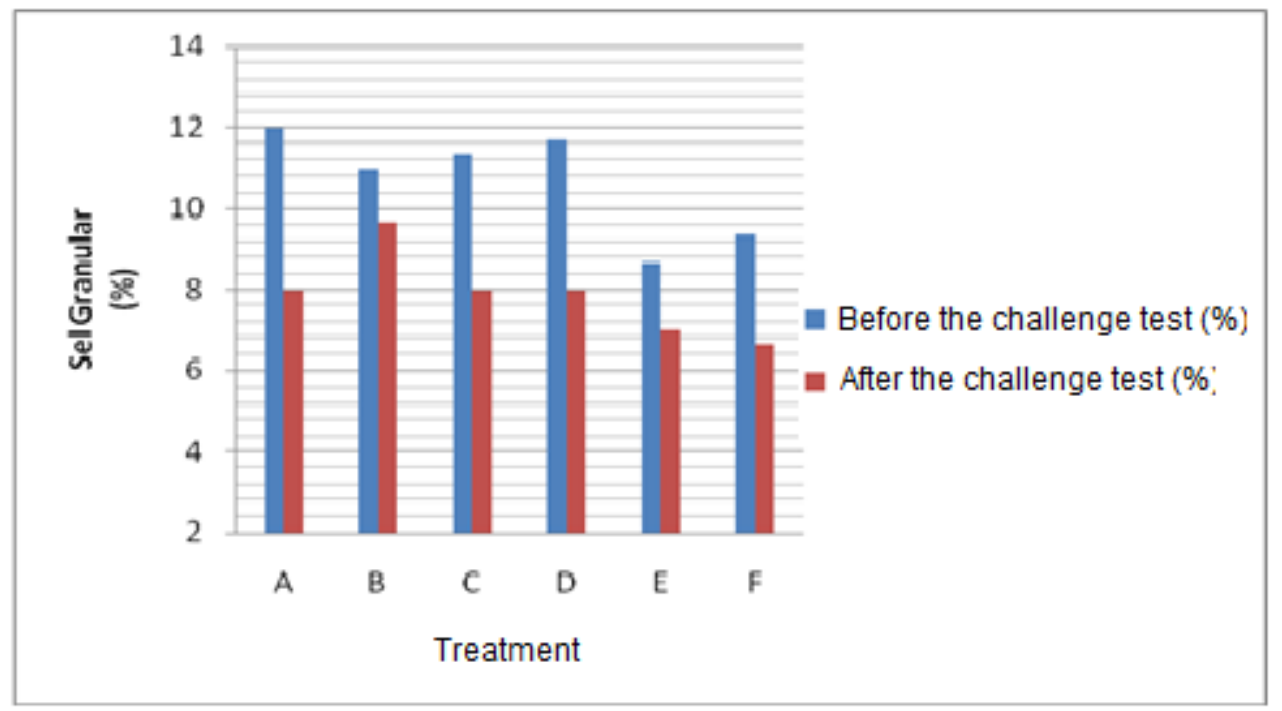

Figure 2. Means of (A) Hyalin Cells, (B) Semi Granular Cells, (C) Granular Cells Vanname Shrimp Before and After IMNV Challenge Test. Treatment A (3 ml); B (6 ml); C (9 ml); D (12 $\mathrm{ml})$; E (0 ml/control -); F (0 ml/control +) per kg food.

It is seen in Figure 2 that different percentage of hemocytes type, and the best result in treatment A. Figure 2A showed high percentage increase in hyalin cells after IMNV challenge test. Hyalin cell is cellular component spread from the whole hemocytes compared with semi-granular cells and granules, as to easily formed and evolved (Sukoso et al., 2012). Hyalin cells have a significant role in microbial phagocytosis process in the body during infection. Based on the greater number of hyalin cells than the other type of hemocyte cells then known that immune response mainly depends on the phagocytosis process taking an important role in cellular defense.

Figure 2B showed a slight percentage increase of semi-granular cells after IMNV challenge test. Semi-granular cells are capable of recognizing and responding to foreign materials or recognized as active cells in encapsulation process (Johanson et al., 2000). Semi-granular cells are capable of recognizing and responding glucosamine in the existence chitosan. In this study, the increase of semi-granular cells have more effective function in the production of phenoloxidase enzyme which is important for humoral defense.

Figure 2C showed that granular cells are decreasing after IMNV challenge test, but they are higher than that of control. Decrease of granular cells was due to its main role in producing, saving, and secreting antimicrobes (Pratiwi, 2008). At the time of infection, granular cells will encounter degeneration and lysis. If infection does not happen, the granular cells will continually increase and multiply cells.

\subsection{Phagocytosis Activity and Content of Anion Superoxide}

Phagocytosis activity and anion superoxide content are proportional with the number of hemocytes, meaning that increase in hemocytes number will be followed by increase of phagocytosis activity and anion superoxide content. 
Table 1. Data on Absorbance Value Of Anion Superoxide and Activity Observation Phagocytosis After IMNV Challenge Test

\begin{tabular}{|c|c|c|}
\hline Treatment & Anion Superoxide Absorbance & Phagocytosis activity (\%) \\
\hline $3 \mathrm{ml} / \mathrm{kg}$ food & 0.084 & 58.08 \\
\hline $6 \mathrm{ml} / \mathrm{kg}$ food & 0.069 & 42.86 \\
\hline $9 \mathrm{ml} / \mathrm{kg}$ food & 0.042 & 24.24 \\
\hline $12 \mathrm{ml} / \mathrm{kg}$ food & 0.034 & 22.14 \\
\hline 0 (negative control) & 0.029 & 12.24 \\
\hline 0 (positive control) & 0.012 & 7.82 \\
\hline
\end{tabular}

Table 1 shows the highest phagocytosis activity in treatment $\mathrm{A}(3 \mathrm{ml} / \mathrm{kg}$ food). Hemocyte in crustacean is the main component of immune system playing its role in the mechanism of phagocytosis, encapsulation, nodulation and cytotoxity medium against foreign materials. Smith (1995) specified that total of hemocytes indicate host capability to respond to foreign materials in the body. The higher number of hemocytes and the higher phagocytosis activity given by the host in controlling foreign organisms. In this study, phagocytosis percentage increases due to the increasing ability of hemocytes when shrimp obtain materials for antigen of chitosan.

Anion superanokxide content is directly proportional with phagocytosis process performed by hemocyte cells. In Table 2, it was obtained data that phagocytosis activity and absorbance value of anion superoxide added with chitosan is higher than control. When microorganisms are digested by hemocytes then some anti microbialanti-microbial substances are produced, one of them is anion superoxide (O-2). Anion superoxide is the first substance produced during respiratory burst catalyzed by NADPH oxidase.

\subsection{Phenoloxidase (PO)}

Phenoloxidase is the last enzyme produced by hemocytes that function in the body defense of shrimp. Phenoloxidase is produced by prophenoloxidase (ProPO) system. Whereas, ProPO is activated by Prophenoloxidase Activating Enzyme (PPA) and the PPA is activated by a polysaccharide such as beta glucan, polysaccharide and peptidoglycan of microorganisms through protein recognition. Prophenoloksidase Activating Enzyme is a protein located in granulocytes.

Table 2. Absorbance Value of Phenoloxidase (PO) After IMNV Challenge Test

\begin{tabular}{|c|c|}
\hline Treatment & Phenoloxidase (PO) \\
\hline $\mathrm{A}(3 \mathrm{ml} / \mathrm{kg}$ food $)$ & 0.070 \\
\hline $\mathrm{B}(6 \mathrm{ml} / \mathrm{kg}$ food $)$ & 0.050 \\
\hline $\mathrm{C}(9 \mathrm{ml} / \mathrm{kg}$ food $)$ & 0.045 \\
\hline $\mathrm{D}(12 \mathrm{ml} / \mathrm{kg}$ food $)$ & 0.030 \\
\hline Negative control & 0.018 \\
\hline Positive control & 0.010 \\
\hline
\end{tabular}

Table 4 explained that phenoloxidase (PO) is obtained in treatment A with $3 \mathrm{ml} / \mathrm{kg}$ food. Findings in this study were quite similar with the findings in the study by Wang and Cheng (2004), chitosan increase PO of vanname shrimp infected with bacterium Vibrio sp. Chitosan is a polysaccharide derivative with glucosamine as the main component. Glucosamine is a 
polymer derivative of microorganisms cellular membrane which is nearly similar with lipopolysaccharide or beta glucan. In this study, chitosan in which glucosamine as the main component, is capable of activating PPA which in turn lead to the activation of proPO and PO in shrimp.

\section{Conclusion and Suggestion}

\subsection{Conclusion}

Conclusion drawn from the study is that chitosan administration in the food can increase non-specific immune response of vanname shrimp to the optimum rate, it is shown in treatment of $3 \mathrm{ml} / \mathrm{kg}$ food after chitosan administration and IMNV challenge test through the observation of THC, DHC, phagocytosis activity, super anionoxide and phenoloxidase (PO) content.

\subsection{Suggestion}

Further study should be better to concentrate on non-specific immune response of vanname shrimp induced with chitosan as immunostimulant against in the presence of different bacteria or viruses infection.

\section{References}

Cheng, W., C. H., Liu, S. T., Yeh, \& J. C, Chen. (2004). The immune stimulatory effect of sodium alginate on the white shrimp Litopenaeus vannamei and its resistance against Vibrio alginolyticus. Fish \& Shellfish Immunology, 17, 41-51. http://dx.doi.org/10.1016/j.fsi.2003.11.004

Cheng, W, C. H., Liu, C. M., Kuo, \& J. C., Chen. (2005). Dietary administration of sodium alginate enhances the immunity ability of white shrimp Litopenaeus vannamei and its resistance against Vibrio alginolyticus. Fish \& Shellfish Immunology, 18, 1-12. http://dx.doi.org/10.1016/j.fsi.2004.03.002

Felix, P., H. Robins, \& A. Rajeev. (2004). Immune Enhancement Assesment of Dietary Incorporated Marine Alga Sargassum wightii (Phaeophyceae / Punctariales) in Tiger Shrimp Penaeus monodon (Crustacia / Penaeidae) Through propenoloxidase (proPO) system. Indian Journal of Marine Sciences, 33(4), 361-364.

Fu, Y. W., W. Y., Hou, S. T., Yeh, C. H., Li, \& J. C., Chen. (2007). The immunostimulatory effects of hot-water extract of Gelidium amansii via immersion, injection and dietary administrations on white shrimp Litopenaeus vannamei and its resistace against Vibrio algynolyticus. Fish \& Shellfish Immunology, 22, 673-85. http://dx.doi.org/10.1016/j.fsi.2006.08.014

Itami. (1994). Body Defense System of Paneid Shrimp, Seminar on Fish Physiology and Prevention of Epizootics, Departement of Aquaculture and Biology. Shimonoseky University of Fisheries. Japan. p : 59-65.

Johansen, M. W., \& Sonderhall, K. (2000). Celuller Imunity in Crustacean and The Pro PO System. Parasit (5). 165 p. 


\section{Macrothink}

Robertsen B, Engstad R. E., \& Jorensen, J. B. (1994). Immunostimulan, Adjuvant, and Vaccine Carries in Fish : aplication to Aquaculture. Annual Review of Fish Deseases. 281-307.

Rodriguez, J., \& G. Le Moullac. (2000). State of The Art of immunological Tools and Health Control of Penaeid Shrimp.Aquaculture., 191, 109-119. http://dx.doi.org/10.1016/S0044-8486(00)00421-X

Soderhall, K, \& Cerenius L. (1992). Crustacean Immunity, Annual Rev. of Fish Diseases. 3-23. http://dx.doi.org/10.1016/0959-8030(92)90053-Z

Sukoso. (2012). Exploration Potential of Marine Yeast. Graduate Program University of Brawijaya. Malang. p:72

Wang, S., \& Chen, J. C. (2004). The Protective Effect of Chitin and Chitosan Against Vibrio alginolyticus In The White Shrimp Litopeaneus vannamei. In Fish and Shelfish Imunology, 19. 191-204.

Van de Braak, K. (2002). Haemocyte Defense in Black Tiger Shrimp (PenaeusMonodon). Proefscrift, PhD. Thesis, Weginen University.158 p.

Van de Braak, K. (2002). Haemocytic Defence in Black Tiger Shrimp (Paneus monodon). Disertasion. Wareningen University. Germany

\section{Copyright Disclaimer}

Copyright reserved by the author(s).

This article is an open-access article distributed under the terms and conditions of the Creative Commons Attribution license (http://creativecommons.org/licenses/by/3.0/). 